\title{
Geodetic and geological evidence of active tectonics in south-western Sicily (Italy)
}

\author{
G. Barreca ${ }^{a}$, V. Bruno ${ }^{\text {b }}$, C. Cocorullo ${ }^{\text {b }}$, F. Cultrera ${ }^{\mathrm{a}, \mathrm{b}}$, L. Ferranti ${ }^{\mathrm{c}, *}$, F. Guglielmino $^{\mathrm{b}}$, \\ L. Guzzetta ${ }^{\mathrm{c}}$, M. Mattia ${ }^{\mathrm{b}}$, C. Monaco ${ }^{\mathrm{a}}$, F. Pepe ${ }^{\mathrm{d}}$ \\ a Dipartimento di Scienze Biologiche, Geologiche e Ambientali, Sezione di Scienze della Terra, Università di Catania, Corso Italia 57, 95129 Catania, Italy \\ ${ }^{\mathrm{b}}$ Istituto Nazionale di Geofisica e Vulcanologia, Osservatorio Etneo - Sezione di Catania, P.zza Roma 2, 95123 Catania, Italy \\ ' Dipartimento di Scienze della Terra, dell'Ambiente e delle Risorse (DiSTAR), Università di Napoli “Federico II", Largo S. Marcellino 10, 80138 Napoli, Italy \\ ' Dipartimento di Scienze della Terra e del Mare, Via Archirafi 22, 90123 Palermo, Italy
}

\section{A R T I C L E I N F O}

\section{Article history:}

Received 20 December 2013

Received in revised form 19 March 2014

Accepted 23 March 2014

Available online 18 April 2014

\section{Keywords:}

Sicilian fold and thrust belt

Geodesy

Active tectonics

\begin{abstract}
A B S T R A C T
Integrated geological, geodetic and marine geophysical data provide evidence of active deformation in south-western Sicily, in an area spatially coincident with the macroseismic zone of the destructive 1968 Belice earthquake sequence. Even though the sequence represents the strongest seismic event recorded in Western Sicily in historical times, focal solutions provided by different authors are inconclusive on possible faulting mechanism, which ranges from thrusting to transpression, and the seismogenic source is still undefined. Interferometric (DInSAR) observations reveal a differential ground motion on a SW-NE alignment between Campobello di Mazara and Castelvetrano (CCA), located just west of the maximum macroseismic sector. In addition, new GPS campaign-mode data acquired across the CCA alignment documents NW-SE contractional strain accumulation. Morphostructural analysis allowed to associate the alignment detected through geodetic measurements with a topographic offset of Pleistocene marine sediments. The on-land data were complemented by new high-resolution marine geophysical surveys, which indicate recent contraction on the offshore extension of the CCA alignment. The discovery of archaeological remains displaced by a thrust fault associated with the alignment provided the first likely surface evidence of coseismic and/or aseismic deformation related to a seismogenic source in the area. Results of the integrated study supports the contention that oblique thrusting and folding in response to NW-SE oriented contraction is still active. Although we are not able to associate the CCA alignment to the 1968 seismic sequence or to the historical earthquakes that destroyed the ancient Greek city of Selinunte, located on the nearby coastline, our result must be incorporated in the seismic hazard evaluation of this densely populated area of Sicily.
\end{abstract}

(C) 2014 Elsevier Ltd. All rights reserved.

\section{Introduction}

Before the occurrence of the 1968 Belice seismic sequence (equivalent moment magnitude of the main shock $\sim 6$ ), the westernmost segment of the Sicilian Fold and Thrust Belt (hereafter, SFTB, Fig. 1) was considered a seismically quiescent region. Focal plane solutions proposed by authors in the last decades show controversial interpretations of the possible geometric and kinematic pattern of the 1968 seismogenic source. Computed focal solutions provide possible faulting mechanisms that range from thrusting on a WSW-ENE striking plane to right lateral transpression on a

\footnotetext{
* Corresponding author. Tel.: +390812538180.

E-mail addresses: g.barreca@unict.it (G. Barreca), luigi.ferranti@unina.it (L. Ferranti).
}

NNW-SSE striking plane (Mckenzie, 1972; Bottari, 1973; Gasparini et al., 1982; Anderson and Jackson, 1987; Frepoli and Amato, 2000). This ambiguity remains still unresolved due to the fact that the source of the 1968 earthquake sequence did not produce a typical seismic landscape (sensu Michetti, 2005) and that, as a result of low magnitude of the events, coseismic fault ruptures have never been observed until now. Moreover, recent deformation in this region has involved mainly clayey lithological units; consequently, exposed fault scarps along the epicentral zone of the 1968 earthquake are unlikely to be observed. For this reason, the identification and characterisation of seismogenic structures in south-western Sicily, and particularly within the Belice area (Fig. 2), has remained an open problem.

A correlation between instrumental and geological data was attempted by Monaco et al. (1996). The authors, based on geological and morphostructural analysis, suggested a NNW-dipping crustal 


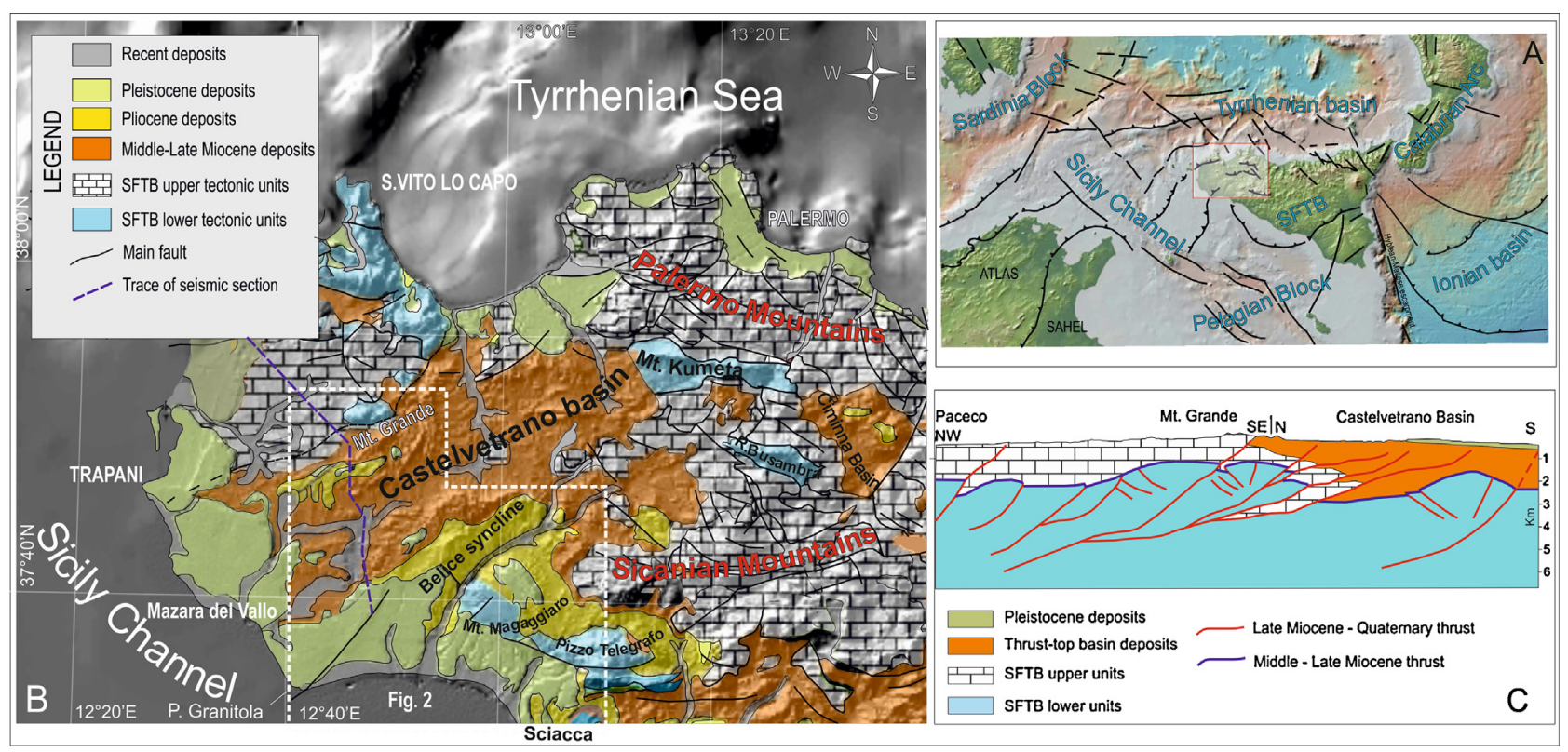

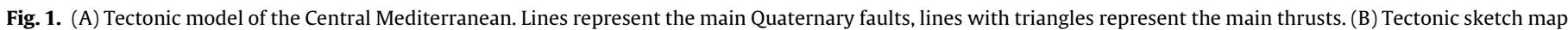
of western Sicily. (C) Geological cross-section (see the trace in Fig. 1B) obtained by seismic interpretation (from Catalano et al., 1989, modified).

blind thrust ramp as the possible seismogenic source for the 1968 Belice earthquake sequence. Accordingly, Lavecchia et al. (2007) consider this area as part of a unique regional-scale seismogenic structure (named Sicilian Basal Thrust) which deepens northward from the front and reaches sub-crustal depths (see also Visini et al., 2010; Sgroi et al., 2012). Notwithstanding, these models do not provide precise constraints on the location and geometric character of the seismogenic sources in the area are.

In this paper, we present the results of a multidisciplinary study including interferometric and GPS data analysis, geological and morphostructural investigation, and marine geophysical survey that reveals recent and active displacement associated with a SW-NE alignment between Campobello di Mazara and Castelvetrano (CCA, Fig. 2) within the seismogenic zone where the 1968 Belice earthquake sequence occurred. The CCA and its eastern extension in the Belice valley are part of the frontal thrust belt in south-western Sicily and, as geodetic and archeoseismological data reveals, is the locus of active deformation that could be responsible for past destructive earthquakes.

\section{Geological setting}

Western Sicily (Fig. 1A) is a segment of the south-migrating SFTB, the emerged portion of a larger orogenic system (the SicilianMaghrebian orogen) which developed in the central Mediterranean region as result of the Neogene-Quaternary Africa-Europe collision processes (Dewey et al., 1989; Ben-Avraham et al., 1990). The SFTB is made up of a pile of thrust sheets deriving from the late Oligocene-middle Miocene deformation of the Neotethys ocean and of the Africa continental palaeo-margin (Bianchi et al., 1987; Roure et al., 1990; Bello et al., 2000; Catalano et al., 2000a,b).

The westernmost segment of the SFTB is a NE-SW oriented contractional belt including imbricates of Meso-Cenozoic carbonate platform and pelagic successions. The structural architecture of the belt is imaged by deep seismic explorations (Catalano et al., 2000a,b; Finetti et al., 2005) that show an upper, 1-3 km thick middle-Late Miocene fold and thrust system, which is superposed on a $\sim 10 \mathrm{~km}$ thick thrust duplex, developed during the PlioPleistocene (Bello et al., 2000; Catalano et al., 2000a,b; Avellone et al., 2010; Barreca et al., 2010; Barreca and Maesano, 2012). Since late Miocene, deep-seated thrusting refolded and breached the previously stacked thrust imbricates and was accompanied by the development of syntectonic marine basins at the footwall of major structures (e.g. the Castelvetrano Basin, Fig. 1B and C). The top of the sedimentary succession is represented by Pleistocene terraced calcarenites, locally deformed by the frontal contractional structures.

In north-western Sicily, the inner portion of the deep-seated thrust system is characterised by the occurrence of high-angle thrusts and associated wide-wavelength folds (Avellone et al., 2010; Barreca and Maesano, 2012). Conversely, in south-western Sicily the frontal thrust faults show flat-ramp geometries (e.g. the Belice and Sciacca area, Fig. 1B), and are involved in lateral extrusion processes produced by the indentation of the orogenic wedge against the rigid part of the Pelagian foreland block (Fig. 1B; Monaco et al., 2000). Frontal thrusting is still seismically active, as indicated by the 1968 Belice Valley destructive earthquake sequence (Monaco et al., 1996; Morelli and Pondrelli, 1998; DISS Working Group, 2010). Accordingly, the seismotectonic processes accommodate active compression at the front of the SFTB and particularly along deep-seated thrust planes (Lavecchia et al., 2007; Visini et al., 2010; Sgroi et al., 2012).

At a more detailed scale, the structural setting of the studied area (Fig. 2) is characterised by NE-SW trending imbricate thrusts that propagated towards the foreland along Miocene to Quaternary sedimentary horizons. Thrusts propagation was accompanied by the development of large and gentle folds (e.g. Fiume Freddo anticline, Vita and Belice syncline, see Monaco et al., 1996 and Fig. 2). This shallow thrust and fold system appears trapped between the two structural culminations of Montagna Grande to the north, and M. Magaggiaro-Pizzo Telegrafo to the south (Fig. 1B, 2). The latter culmination originated from deep-seated thrusting that deformed part of the Pelagian foreland (Tortorici et al., 2001).

Recent tectonic activity is testified by folded Late Quaternary terraces and lacustrine deposits, outcropping at the frontal and shallower sector of the thrust and fold system, south of Pizzo Telegrafo. For a more detailed description of the recent tectonics in the Belice area, see Monaco et al. (1996). 


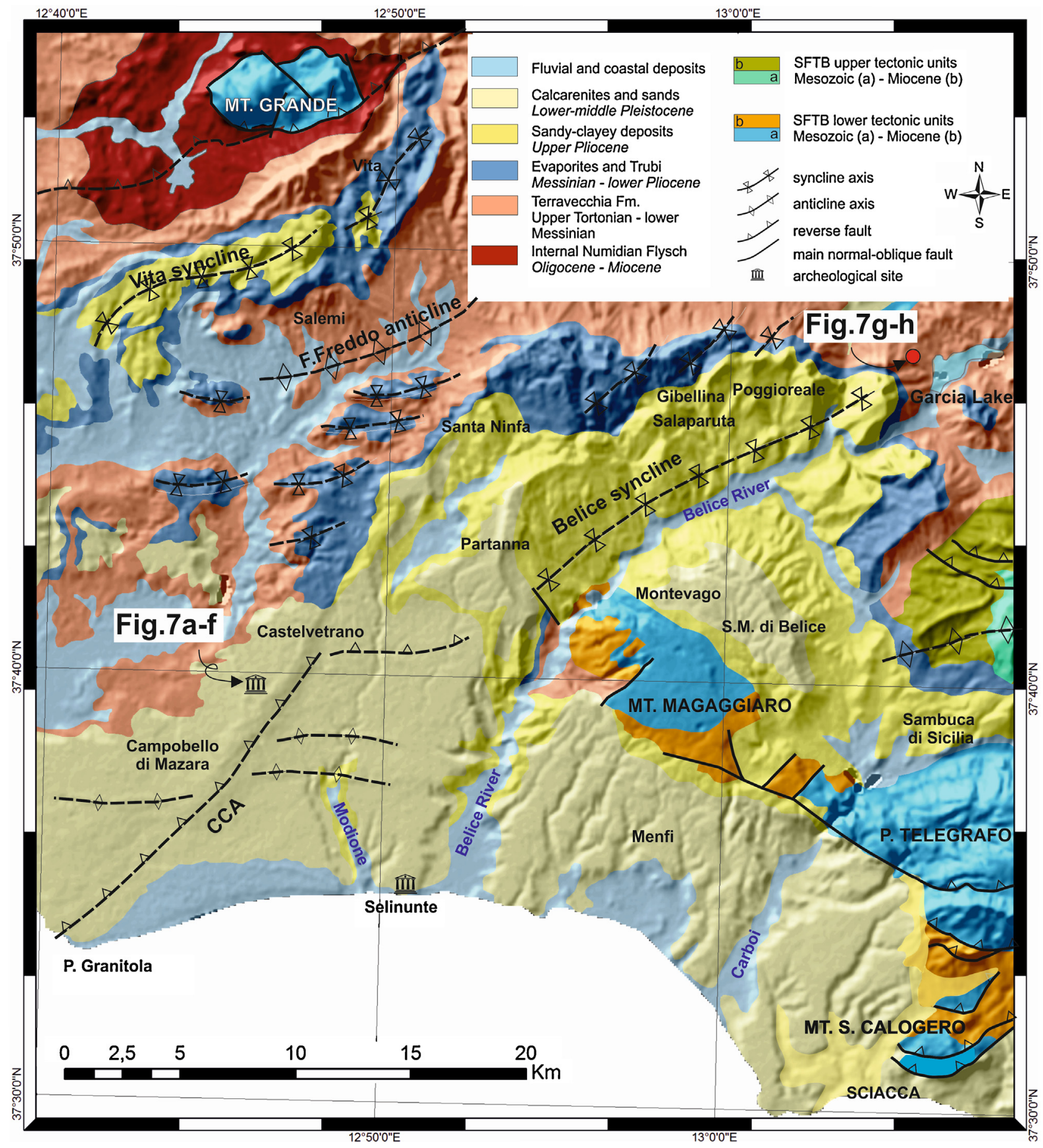

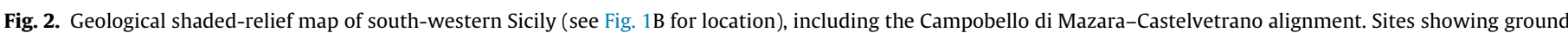
deformation are evidenced.

\section{Seismotectonics of south-western Sicily}

Geoarchaeological evidences indicate the occurrence of two ancient earthquakes that destroyed the old Greek colony of Selinunte, located $4 \mathrm{~km}$ west of the Belice River mouth (Fig. 2). These earthquakes, documented by the collapse of Greek temples in Selinunte, occurred between 370 and 300 B.C. and between 300 and 600 A.D. (Guidoboni et al., 2002; Bottari et al., 2009). Nevertheless, before the 1968 Belice seismic sequence, the westernmost segment of the SFTB was considered a seismically almost quiescent region. Anyhow, with the exception of these destructive earthquakes, historical and instrumental records reveals that the seismicity of south-western Sicily is characterised by sparse low-moderate magnitude earthquakes with epicentres distributed from the contractional belt to the Sicily Channel rift (ISIDE database; http://iside.rm.ingv.it/iside/standard/index.jsp; see also Rigano et al., 1999; Rovida et al., 2011).

The 1968 seismic sequence is the only important seismic event occurred in the area after the Roman colonisation. From the 14th to the 25th of January, 1968, a high frequency seismic swarm (more 


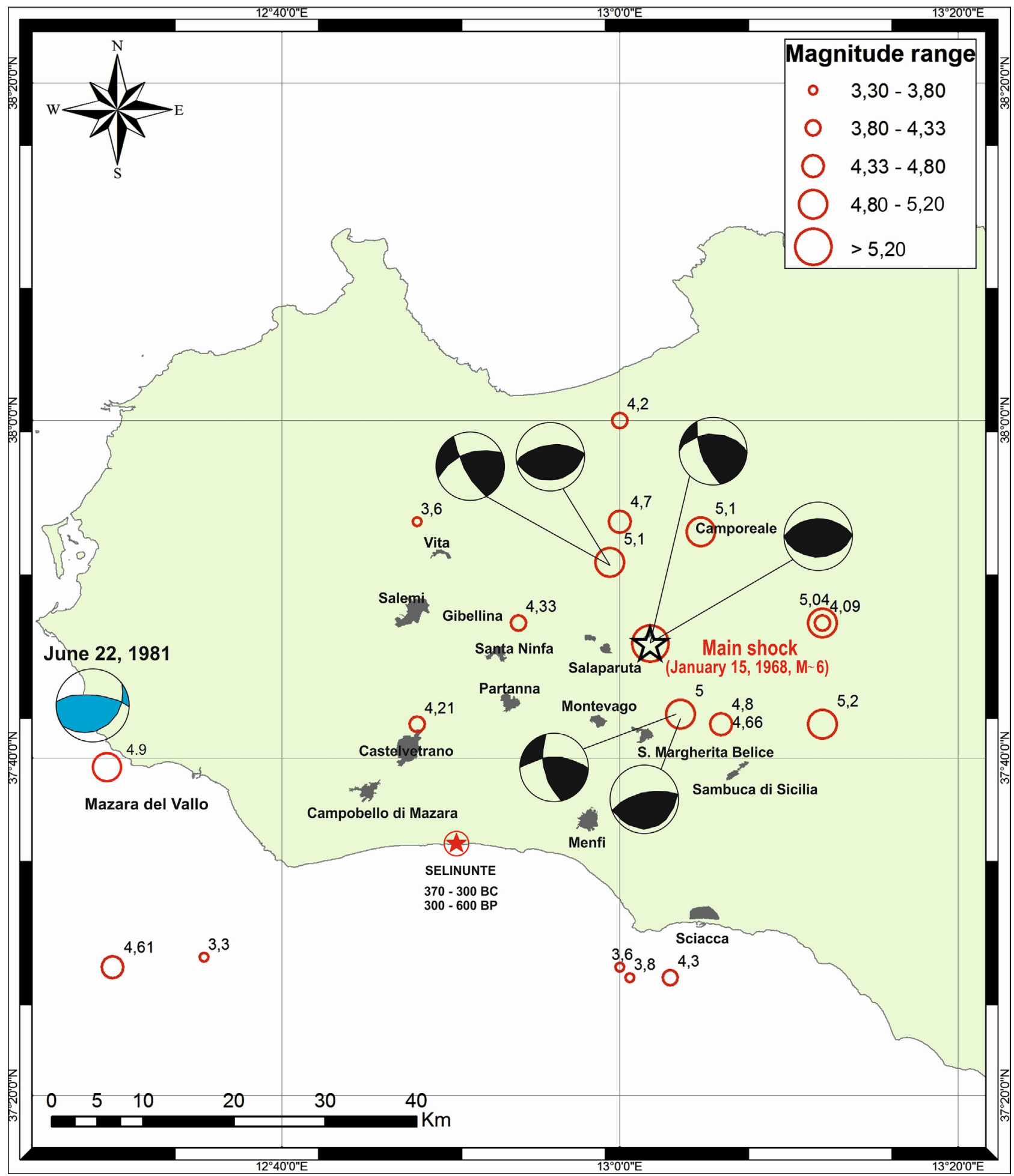

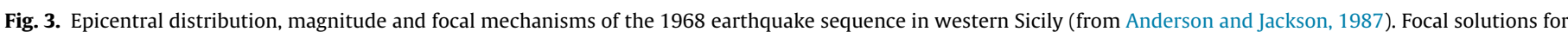

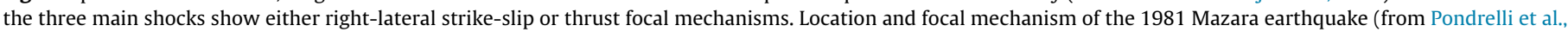
2006), and location and age of seismic destruction of the ancient Greek colony of Selinunte are also shown.

than 300 events) affected the Belice valley area (Fig. 3; De Panfilis and Marcelli, 1968; Marcelli and Pannocchia, 1971; Bottari, 1973; Anderson and Jackson, 1987; Rovida et al., 2011), causing severe damaging of fourteen villages, four of which (Gibellina, Poggioreale, Salaparuta and Montevago) were almost completely destroyed. The seismic swarm nucleated along the whole crustal depth $(1-39 \mathrm{~km})$, and epicentres were distributed over a large part of south-western
Sicily (Fig. 3). Most events were aligned along the SW-NE oriented Belice River Valley. The main shock $(\mathrm{M} \sim 6)$ occurred on January 15 and was a superficial event ( $\sim 3 \mathrm{~km}$; Anderson and Jackson, 1987) located along the axis of the Belice syncline (see Monaco et al., 1996).

Ground effects related to the 1968 earthquakes were generally scarce and occurred mainly at the northern limb of the Belice 

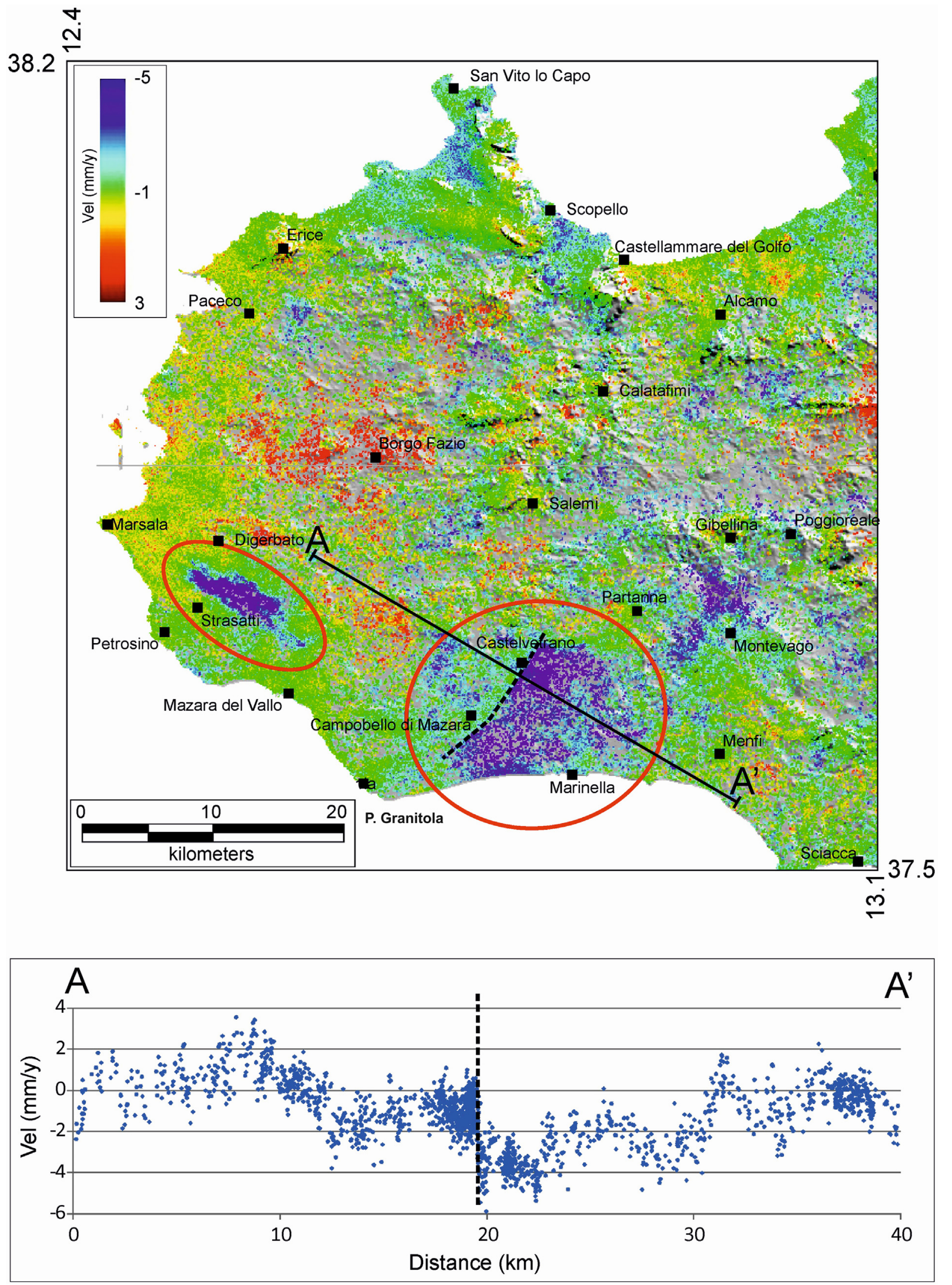

Fig. 4. Mean Ground velocities calculated on persistent scatterers by the StaMPS package, using the descending SAR imagery of ENVISAT spacecraft from 2003 to 2010. 


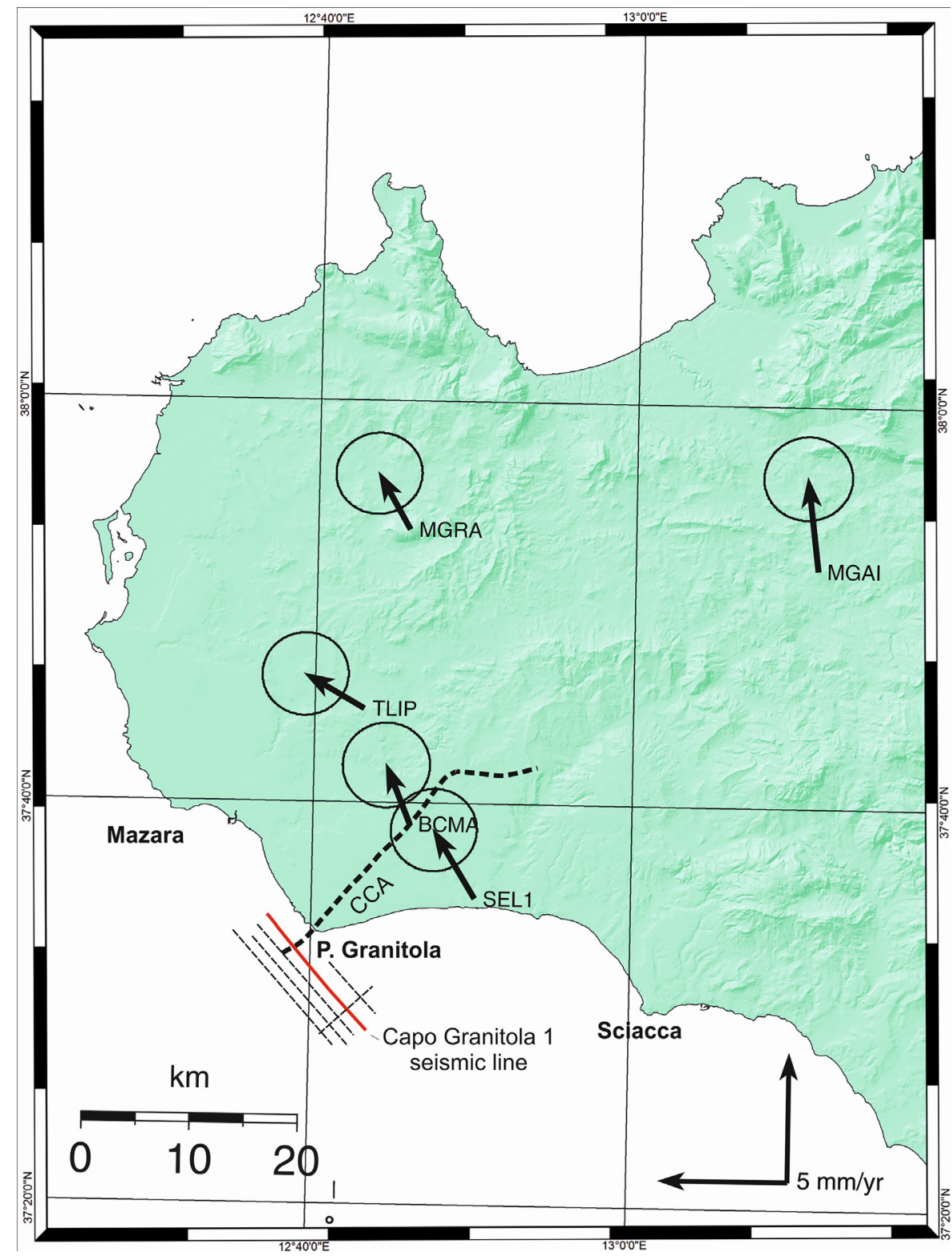

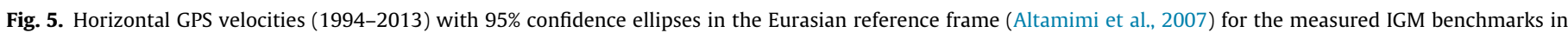
western Sicily.

syncline, where they consisted of small landslides, mud upraise along fractures and fluids escape (Bosi et al., 1973; Michetti et al., 1995). Despite numerous attempts to associate the 1968 swarm to a specific seismogenic fault (e.g. Antonelli et al., 1988; Scandone et al., 1992; Michetti et al., 1995; Monaco et al., 1996; Argnani, 1990), no evidence of fault breaks at the epicentral zone were reported. In the focal solutions proposed in the literature for the Belice 1968 seismic sequence (Fig. 3), the average $P$-axis is low-dip and nearly $\mathrm{N}-\mathrm{S}$ trending, compatible with a right-lateral component of motion along NNW-striking planes or, alternatively, with thrusting mechanisms along ENE-trending planes (Anderson and Jackson, 1987). NNW-SSE oriented $P$ axes and reverse pure mechanisms were proposed by Mckenzie, 1972. An almost pure reverse mechanism with a nearly N-S $P$-axis is also shown by the Mazara 1981 earthquake with Mw 4.9, located (Fig. 3) about $30 \mathrm{~km}$ to the west of the Belice area (Pondrelli et al., 2006; Lavecchia et al., 2007).

The scarce geodetic data available for the frontal belt of south-western Sicily preclude precise quantification of current contractional strain accumulation. Although detectable contraction was only observed further east along the Sicilian front and on the northern rim of the Hyblean plateau, the broad surface velocity pattern suggested that transpressional strain accumulation is still occurring in southwestern Sicily (Ferranti et al., 2008; Devoti et al., 2011; Mattia et al., 2012; Palano et al., 2012).

\section{Multidisciplinary analysis of active tectonics}

\subsection{Interferometric SAR data}

In this study, we measured ground deformation rates in western Sicily through the A-DInSAR StaMPS method (Stanford Method for Persistent Scatterers, Hooper, 2008), using image data from the ESA ENVISAT satellite spanning the time period 2003-2010. This approach, based on the Persistent Scatters Interferometry, permits to retrieve estimates of the displacements occurring between different acquisitions of SAR data, distinguishing the phase shift related to ground motions from the phase component, due to atmosphere, topography and noise through a statistical analysis of the 
signals backscattered from a network of individual phase coherent targets. Focused SAR images were produced using the ROI_PAC software package developed by JPL (Rosen et al., 2004) and the interferometric processing was performed using the Doris software package (Kampes et al., 2003) developed by the Delft University of Technology. The SAR dataset analysed in this work comprises 37 ENVISAT images from 2003 to 2010, acquired from Track 308 descending orbit. To remove the topographic component from the interferometric phase we used an SRTM DEM (Farr et al., 2007) which has a resolution of 3-arcsecond ( $\sim 90 \mathrm{~m})$.

Inspection of the Line Of Sight (LOS) mean velocity map evidenced two areas characterised by differential ground motion (Fig. 4): (i) the first area trends NW-SE and is located between the towns of Marsala and Mazara del Vallo; (ii) the second area marks, with a roughly SSW-NNE orientation, the abrupt decay of ground velocity along the Campobello di Mazara-Castelvetrano (CCA) alignment.

The Marsala-Mazara anomaly show a maximum subsidence of $4 \mathrm{~mm} / \mathrm{yr}$, over an area of about $20 \mathrm{~km}^{2}$. It is located on the Marsala Plain aquifer, where in the last decade a water table lowering $(\sim-20 \mathrm{~m})$ has been reported by government monitoring (http://www.regione.sicilia.it/presidenza/ucomrifiuti/acque/ DOCUMENTI/DOCUMENTI_E/E3/MARSALA/inquadramento.pdf).

This subsidence is due to the intense pumping from water wells. This opinion is funded on the fact that 25 wells pumping in this area on average $325 \mathrm{l} / \mathrm{s}$ for water supply can be able to produce (Custodio, 2002) a general condition of subsidence. Based on this, we suggest that overexploitation (and the consequent subsidence) caused the perturbation in the LOS velocity map, and we discarded this area from further analysis.

On the other hand, the Campobello di Mazara-Castelvetrano alignment, characterised by up to $2 \mathrm{~mm} / \mathrm{yr}$ differential ground motion, does not appear to be directly associated to any human activity. This, in addition to its trend and length, allow to consider the alignment of tectonic origin and motivated further research.

\subsection{GPS data}

In 1992 the Italian IGM (Istituto Geografico Militare www.igmi.org) started the GPS measuring of a network made up of 1260-bechmarks, about $20 \mathrm{~km}$ far from each other and extended over the whole Italy. The measurements were performed to improve the national reference system, both for cartographic and geodetic purposes.

We have reoccupied five IGM benchmarks in south-western Sicily (Fig. 5, Table 1) in order to calculate the surface velocity map and to obtain independent information on strain accumulation on the CCA alignment revealed by interferometric data. The GPS survey was carried out using Leica GX1220 receivers and AR10 antennas, while instruments used by the IGM in 1994 were Trimble 4000 SSE receivers and Trimble compact with groundplane (model 22020-00) antennas. Every single session of data acquisition span 4-5 h for the first IGM campaign in 1994 and 5-13 h for the 2013 survey. We processed the GPS data using the GAMIT/GLOBK software (Herring et al., 2010) with IGS (International GNSS Service) precise ephemerides and Earth orientation parameters from the
IERS (International Earth Rotation Service). In the first step we used the GPS phase observations from each surveyed day to estimate station coordinates, the zenith delay of the atmosphere at each station, Earth orientation parameters and associated error covariance matrices. In the second step, the loosely constrained estimates of the previous processing phase for each surveyed day were used as quasi observations in a Kalman filter to estimate a consistent set of coordinates and velocities. We tied the measurements to an external global reference frame by including in our analysis the data from seven CGPS stations belonging to the IGS and EURA networks and operating since 1994 (GRAZ, HERS, JOZE, MADR, ZIMM). The quasi-observations were then combined with global solutions (IGS1, IGS2, EURA) provided by the Scripps Orbital and Permanent Array Centre (SOPAC) at UC San Diego. The loosely constrained daily solutions were transformed into ITRF2005 (2005 International Terrestrial Reference Frame; Altamimi et al., 2007) and then rotated into a fixed Europe reference frame.

The errors in velocities were considered a combination of white and random walk noise (McCaffrey et al., 2007). In particular, for the non-permanent GPS velocities we added $2.5 \mathrm{~mm} / \mathrm{yr}$ of random noise and 3.0 and $3.5 \mathrm{~mm} / \mathrm{yr}^{1 / 2}$ of random walk noise for the horizontal and vertical components respectively, that highly depends on the satellite and tracking network (both weaker in the earlier years of the measurements).

The European velocity field (Fig. 5) shows that the GPS stations of western Sicily move with velocities ranging from about 2.6 to $3.6 \mathrm{~mm} / \mathrm{yr}$ along NNW to NW directions. Noteworthy, velocity values decrease from south to north from about $3.1 \mathrm{~mm} / \mathrm{yr}$ (SEL1 GPS station) to $2.5 \mathrm{~mm} / \mathrm{yr}$ (BCMA and TLIP) across the CCA alignment (Fig. 5 and Table 1 ).

\subsection{Morphostructural data}

A geological and morphostructural analysis was performed with the aim to verify whether current ground deformation across the CCA alignment indicated by interferometry and GPS data, is reflected by geological and morphological features. For this purpose, available geological maps (sheets $n^{\circ} 257$ Castelvetrano and $\mathrm{n}^{\circ} 265$ Mazara del Vallo of the Carta Geologica d'Italia, 1955-1956) have been upgraded with original field surveys, that were supported by the morphometric analysis of a $2 \mathrm{~m} \times 2 \mathrm{~m}$ grid resolution DEM and by the interpretation of 1:10,000 scale aerial photographs.

Analysis revealed that the differential ground motion provided by interferometric data matches with an up to $\sim 60 \mathrm{~m}$ sharp topographic break (Fig. 6) recorded within lower-middle Pleistocene terraced calcarenites just north-west of the CCA (Fig. 2). The terrace extends at elevation of 100-150 m above sea level and slightly slopes $\left(0-5^{\circ}\right)$ to the south, occasionally interrupted by river channels (e.g. Belice and Modione rivers). A series of tightly $(2.5 \mathrm{~km})$ spaced topographic profiles (Fig. 6), across the NNE-SSW oriented slope evidenced the salient morphometric feature of the up-raised part of the terrace, that is characterised by a narrow ( $\sim 1 \mathrm{~km}$ wide) asymmetric ridge. This morphological setting appear continuous as far as to the coastal area, where the elevation become less pronounced, and corresponds to a recent anticline whose eastern limb slopes at about $10-15^{\circ}$ towards the south-east (Fig. 7a).

Table 1

GPS Velocities and associated one standard error of the IGM GPS benchmarks (see Fig. 5 for benchmarks location).

\begin{tabular}{|c|c|c|c|c|c|c|c|c|c|}
\hline GPS site & & Long. & Lat. & $\begin{array}{l}\text { E velocity } \\
(\mathrm{mm} / \mathrm{yr})\end{array}$ & $\begin{array}{l}\text { N velocity } \\
(\mathrm{mm} / \mathrm{yr})\end{array}$ & $\begin{array}{l}\text { E sigma } \\
(\mathrm{mm} / \mathrm{yr})\end{array}$ & $\begin{array}{l}\mathrm{N} \text { sigma } \\
(\mathrm{mm} / \mathrm{yr})\end{array}$ & $\begin{array}{l}\text { U velocity } \\
(\mathrm{mm} / \mathrm{yr})\end{array}$ & $\begin{array}{l}\text { U sigma } \\
(\mathrm{mm} / \mathrm{yr})\end{array}$ \\
\hline MGAI & Monte Galiello & 13.193 & 37.864 & -0.44 & 3.57 & 0.7 & 0.66 & -2.35 & 1.07 \\
\hline SEL1 & Selinunte (tempio di Hera) & 12.836 & 37.587 & -1.6 & 2.61 & 0.68 & 0.65 & -1.55 & 1.08 \\
\hline BCMA & Bivio per Campobello di Mazara & 12.766 & 37.648 & -0.92 & 2.25 & 0.69 & 0.67 & -0.76 & 1.09 \\
\hline MGRA & Montagna Grande & 12.762 & 37.895 & -1.23 & 2.13 & 0.68 & 0.64 & 0.37 & 1.04 \\
\hline TLIP & Timpone Lippone & 12.716 & 37.745 & -2.26 & 1.29 & 0.68 & 0.65 & -1.6 & 1.05 \\
\hline
\end{tabular}




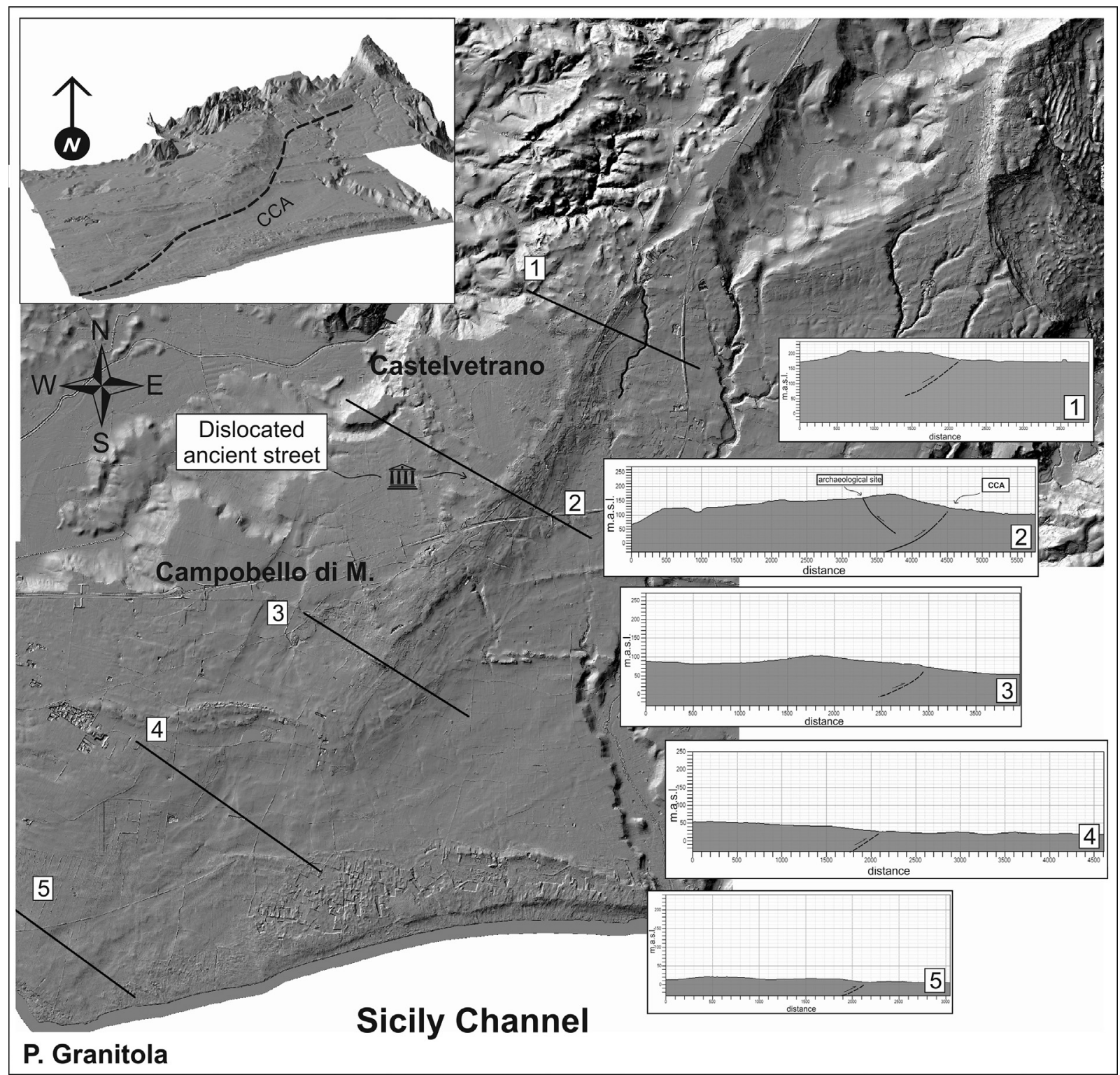

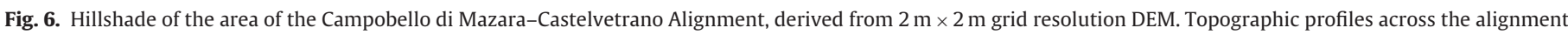
showing the antiformal morphology.

Meso-structural measurements within the ridge revealed that the calcarenite is cut by a set of SSW-NNE trending, conjugate reverse faults (Fig. 7b and c). Just south of Castelvetrano, an archaeological site is set on the Pleistocene calcarenites rimming the CCA slope (Fig. 2), and has an age range spanning from Bronze to ancient Greek age (De Miro, personal communication). A street within the ancient settlement (Fig. $7 \mathrm{~d}$ ) is dislocated $\sim 5 \mathrm{~cm}$ by a N30E striking reverse fault, dipping $\sim 50^{\circ}$ towards the SE (Fig. 7e). Southwest of the ancient street, the trace of the fault is marked by cracks within the asphalt of a modern street (Fig. 7f).

To the north-east, in the Belice River valley, the only evidence of active deformation was found close to the Garcia Lake, $\sim 5 \mathrm{~km} \mathrm{NE}$ of Belice main epicentral area (Fig. 2). Here, a concrete side-wall of the road by-passing the Lake is displaced by a W-E trending reverse fault (Fig. $7 \mathrm{~g}$ ). The sidewall, founded on clays, shows at present an offset of $\sim 10 \mathrm{~cm}$, but it has been completely reconstructed in the last 7 years, as testified by a 2006 GOOGLE street view image, which shows the older side-wall affected by similar contractional structures (Fig. 7h). A geomorphological survey of the area allowed us to exclude the occurrence of surface gravitational processes at this site. On the other hand, the strike of the reverse fault is parallel to the maximum slope gradient. For this reasons we interpret this ground deformation as the result of tectonic creep, even though the clayey lithology of the substratum do not allow a precise extensive survey of the fault structure.

\section{Marine seismic reflection profiles}

A grid of high-resolution reflection seismic profiles was recorded in August 2013 along the continental shelf in the offshore of Punta Granitola (see Fig. 6 for location) with the purpose of verifying the south-west prolongation of the CCA. The acoustic source used during seismic prospecting was a $1 \mathrm{~kJ}$ Sparker power supply with a multi-tips Sparker array, which lacks ringing and has a base frequency of around $800 \mathrm{~Hz}$, fired at a time interval of $1.5 \mathrm{~s}$. Data were recorded using a single-channel streamer with an active 

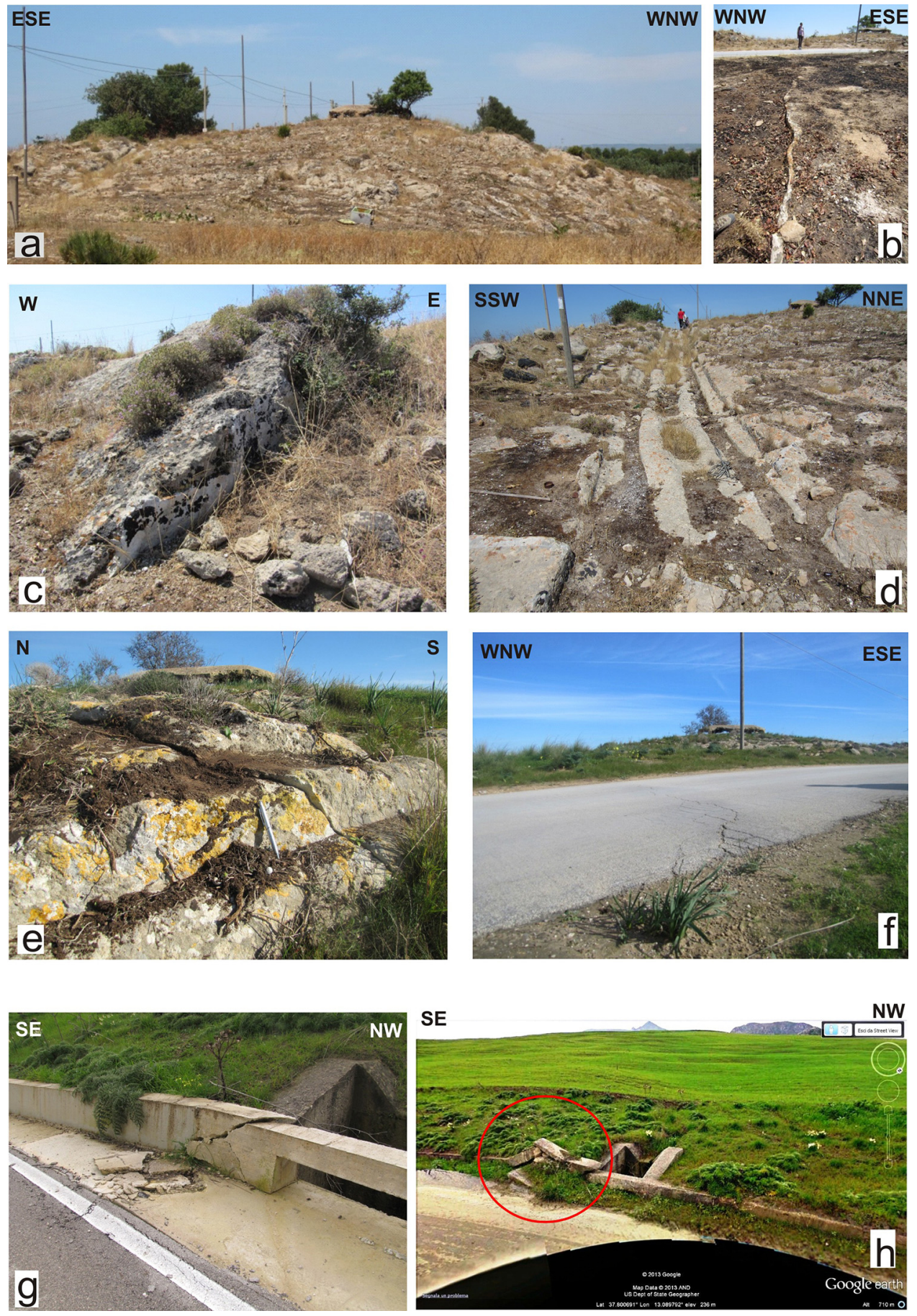

Fig. 7. Field evidence of active deformation (see Fig. 2 for location of pictures): (a) SW-NE trending anticline between Castelvetrano and Campobello di Mazara, deforming lower-middle Pleistocene terraced calcarenites (see); (b) and (c) conjugate reverse faults, coaxial with the anticline of (a); (d) and (e) street within the ancient settlement of Castelvetrano dislocated by a N30E striking back-thrust (same location of a-c); (f) cracks within the asphalt of a modern street parallel to the ancient street; (g) concrete side-wall of the road by-passing the Garcia Lake displaced by a W-E trending reverse fault; (h) 2006 GOOGLE street view image, showing an older side-wall in the same position of $(\mathrm{g})$, affected by similar ground deformation.

section of $2.8 \mathrm{~m}$, containing seven high-resolution hydrophones, for $0.5 \mathrm{~s}$, two way time (t.w.t.) at a $10 \mathrm{kHz}(0.1 \mathrm{~ms})$ sampling rate. Positioning was controlled by a Differential Global Positioning System.

Seismic data processing was performed using the Geo-Suite AllWorks software package, running the following mathematical operators: spherical divergence correction, de-ghosting, migration, band-pass (300-2000 Hz) filter, swell filter, trace mixing, time variant gain and mute of water column. Signal penetration was found to exceed $500 \mathrm{~ms}$ t.w.t. The vertical resolution is $\sim 1 \mathrm{~m}$ near the seafloor.

\subsection{Seismo-stratigraphic analysis}

Four seismic units were identified along the study area based on the internal configuration and external shape of the seismic units. These units are labelled CM, A, B and C, from youngest to oldest 

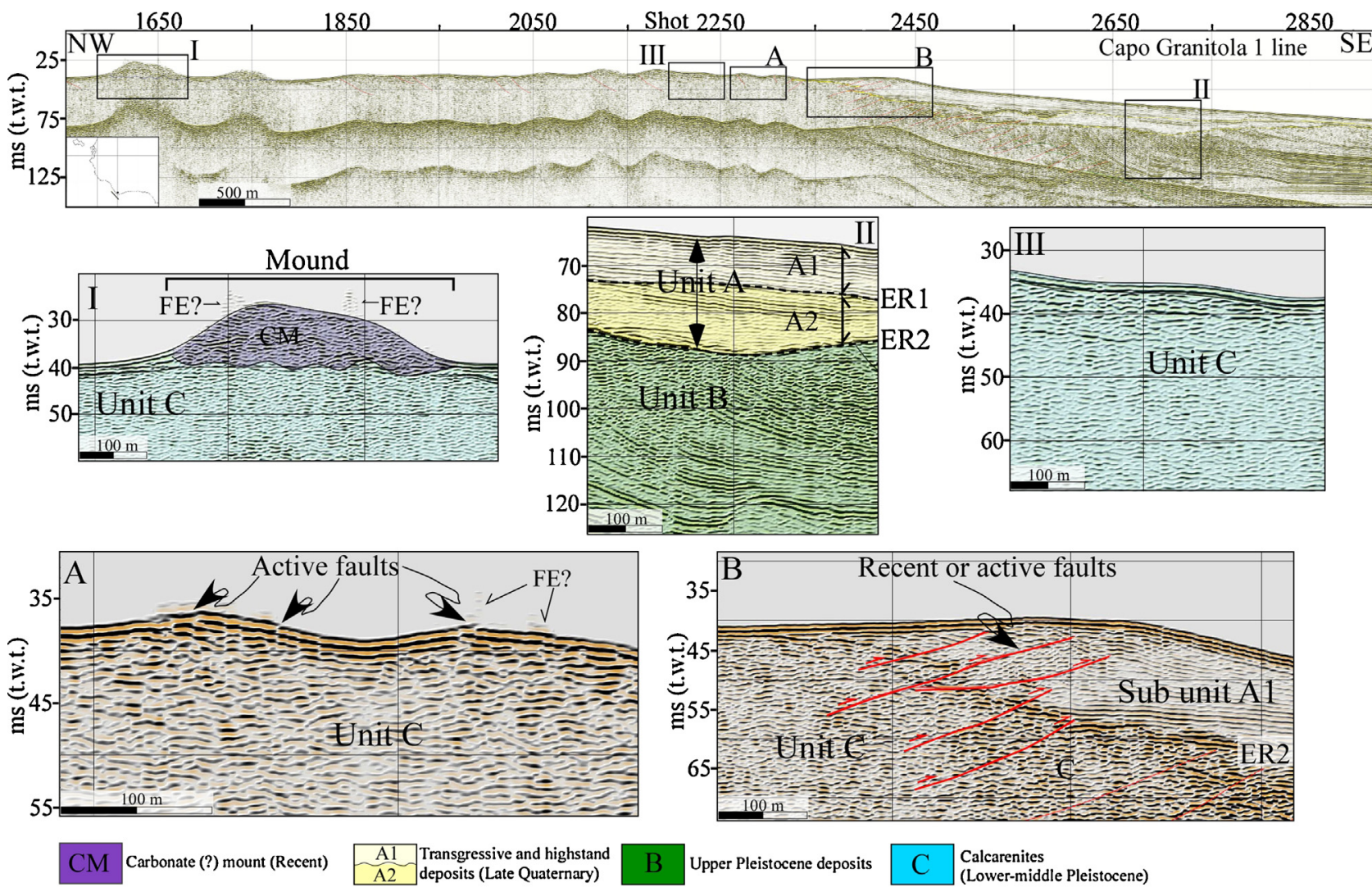

FE, fluid escape; ER1 and 2, erosional surface

Reverse fault

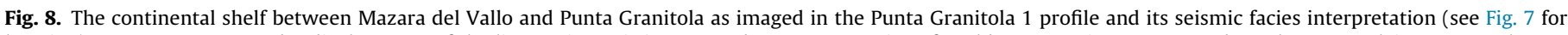

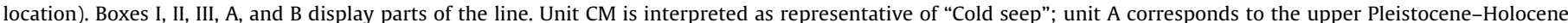

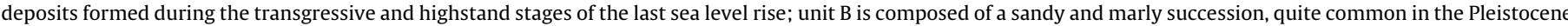

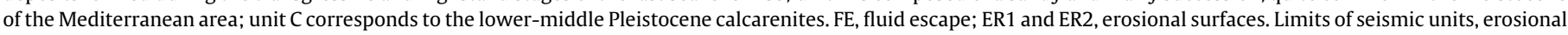
surface and internal subdivision of unit A into lower (A2) and upper (A1) subunits are evidenced by thick dashed lines.

(Fig. 8). Seismic characteristics such as amplitude, reflection continuity, external shape, and frequency allow us to infer depositional processes operating in the study area (Damuth, 1980).

Unit CM is mound-shaped, and shows highly irregular internal reflection patterns with occasionally strong discontinuous internal reflections. Underneath the mound structures, the seismic signal is characterised by irregular to chaotic, mostly discontinuous, moderate- to locally high-amplitude reflections. The reflection amplitude variation is interpreted as a due to the diffuse occurrence of pore fluids (Fig. 8, inset I). This seismic facies was locally recognised in the north-western sector of the investigate area only above the Unit C (see below). On the basis of the external shape and seismic facies, Unit CM is tentatively interpreted as representative of "Cold seep". The absence of sediments above it suggests that the growth of cold seep is still active.

Unit A was only recognised moving south-westward from Punta Granitola. It can be seismically subdivided into two subunits named A1-A2. Sub-Unit A1 exhibits slightly seaward dipping, welldefined, high-amplitude and laterally continuous reflections with parallel geometry. The top of sub-Unit A1 is defined by the seafloor while the lower bounding surface correspond to an erosional surface (ER1 in Fig. 8, inset II). Reflections of Sub-Unit A1 slightly diverge and display a clinoform geometry in the area close to the Capo Granitola. Sub-Unit A2 has discontinuous, moderateamplitude reflections. It is marked at the base by an high-amplitude and well-defined laterally continuous event, which correspond to a sub-aerial erosional surface (ER2 in Fig. 8, inset II). The latter is interpreted has having formed during the still-stand associated with the Last Glacial Maximum. Based on its stratigraphic position, we associated Unit A with the upper Pleistocene-Holocene deposits formed during the transgressive and high-stand stages of the last sea level rise. The ER1 marine erosional surface formed during the sea-level rise following the LGM.

Unit B is characterised by a succession of well-stratified, seaward dipping (the proximal portion), high-frequency, and medium- to high-amplitude reflections of good lateral continuity, with parallel (the distal portion) to divergent (the proximal portion) internal configuration (Fig. 8, inset II). This seismic facies can be correlated with a sandy and marly succession quite common in the Pleistocene of the Mediterranean area (Pepe et al., 2003 and references therein).

Unit $C$ is seismically characterised by medium- to highamplitude, discontinuous reflections (Fig. 8, inset III). Northwestwards, the top of Unit C corresponds to an irregular surface coinciding with the seafloor. We attribute this seismic facies to the lower-middle Pleistocene calcarenites that are widespread along most of the onshore sector between Mazara del Vallo and Punta Granitola (Fig. 1).

\subsection{A section across offshore prolongation of the CCA}

The Capo Granitola 1 seismic profile shows that the lowermiddle Pleistocene calcarenites (Unit C) are widespread at shallow water depth $\sim 25 \mathrm{~m}$ (coinciding with the sea-floor) along the continental shelf offshore of Punta Granitola, while their top rapidly deepens moving southeast-ward and are not detected from the shot 2650 to the end of the profile within the first $50-70 \mathrm{~m}$ beneath 
the sea-floor (Fig. 8). From the shot $\sim 2350$ to the southwest part of the profile, the lower-middle Pleistocene calcarenites are unconformably overlain by the late Pleistocene-Holocene deposits. These latter are thin or absent moving NW of Punta Granitola, along the continental shelf, at water depth less than $\sim 30 \mathrm{~m}$, suggesting that this sector experienced uplift during Quaternary.

Small scale, NW- and SE-displacing reverse faults are observed along the continental shelf (Fig. 8, shots 1550-2350). In particular, the seismic section clearly shows small scale reverse faults, in the offshore extension of the CCA (see inset A in Fig. 8), where they cut the lower-middle Pleistocene calcarenites and offset the seafloor, confirming their recent activity. Towards the SE, south-east-verging, reverse faults affect lower-middle Pleistocene calcarenites as well as the late Pleistocene-Holocene layers (see inset B in Fig. 8), suggesting that fault displacement acted during the post-LGM. Here, individual reverse faults generally show horizontal and vertical displacements of the top calcarenites of up to $\sim 60 \mathrm{~m}$ and $\sim 5 \mathrm{~m}$, respectively.

Expulsions of fluids from the deformed calcarenites have also been observed along the continental shelf where mount-shaped, cold-seep communities formed (Fig. 8, inset I). In dip section, the sea mounts are up to $\sim 450 \mathrm{~m}$ long and $\sim 9 \mathrm{~m}$ high, arranged in clusters oriented $\mathrm{N}_{45} \mathrm{E}^{\circ}$. This orientation is similar to the $\mathrm{SW}$ offshore prolongation of the CCA, thus suggesting a close relationship between expulsions of fluids, cold-seep communities and active faults.

\section{Discussion}

New morphometric and marine geophysical analysis, corroborated by interferometric and GPS data, document that active contraction occurs in south-western Sicily within the seismic zone of the 1968 Belice earthquake sequence. Integration of on-land and offshore data lead us to propose that the sharp topographic break within the lower-middle Pleistocene calcarenites along the CCA can be attributed to blind, thrust-related antiformal folding. This interpretation is consistent with the structural style of the region, suggesting that folding nucleated in response to south-eastward slip on a deep-seated thrust which cores a blind culmination of the SFTB internal units (Fig. 1c). Noteworthy, the new offshore seismic profiles show that recent thrusting continues to the south-west in the Sicily Channel (Fig. 8). To the west, active tectonics with similar structural pattern have been observed in northern Algeria Maghrebides (e.g. the 1980 El Asnam earthquake, Meghraoui et al., 1988).

Deep-seated slip and associated shallow-crustal folding is still active as suggested by deformation of ancient and modern artefacts and buildings (Fig. 7), and thus the question arises whether the CAA alignment is part of an unknown seismogenic structure in south-western Sicily. The source of the 1968 seismic sequence remained elusive so far. However, according to focal plane solutions provided by Mckenzie (1972), the mechanisms for these events were thrust with NNW-SSE oriented $P$ axes. This interpretation is consistent with our morphostructural data, with the observed differential GPS velocity and with the location of the interferometric anomaly, which indicate strain accumulation in response to NNW-SSE oriented compression.

The observed deformation occurs along a SW-NE oriented blind thrust system that extends from the offshore of P. Granitola to Castelvetrano (Fig. 2). East of here, the system swings to a WSW-ENE trend and may run under the Belice valley as far east as to the Garcia Lake. The newly proposed blind, segmented fault system largely encompasses the seismic zone relative to the 1968 Belice earthquake sequence, as recently redefined by the Italian government (http://www.protezionecivile.gov.it/ jcms/it/classificazione.wp). In particular, active deformation is mostly focused south-west of the epicentral area, between Castelvetrano and Campobello di Mazara, where faulted archaeological features are located about $25 \mathrm{~km}$ from the epicentral zone. In our opinion, the observed ground deformation is not directly associated to the 1968 Belice sequence, but might be related to past earthquakes (e.g. the IV century B.C. and the IV-V century A.D events that destroyed the old Greek colony of Selinunte, see Guidoboni et al., 2002; Bottari et al., 2009). Taking into account the displacement $(\sim 5 \mathrm{~cm})$ of the ancient road along the CCA, and according to the empirical relationships of Wells and Coppersmith (1994) for reverse faults, this deformation can be related to an $\mathrm{M} \sim 6$ earthquake, capable of destroying the nearby temples of Selinunte and near to the magnitude value provided by seismological data for the 1968 Belice main shock. Although our observations indicate that stress is at present released as aseismic creep (Fig. 7e-g), past coseismic ruptures could have occasionally propagated up to the earth surface.

\section{Conclusions}

Integrated geological, geodetic and marine geophysical data provide evidence of active deformation in south-western Sicily, in an area spatially adjacent to the macroseismic zone of the destructive 1968 Belice earthquake sequence. In general, seismotectonic processes accommodate active compression at the front of the chain, resulting in surface folding and fracturing in response to south-eastward verging deep-seated thrusts. This is in good agreement with previous interpretations (Monaco et al., 1996; Lavecchia et al., 2007), that suggested the occurrence of a NNW-dipping crustal blind thrust ramp, belonging to a regional-scale seismogenic structure, as the possible source for the 1968 Belice earthquake sequence.

Notwithstanding the remaining ambiguity on the 1968 earthquake source, our analysis confirm and refine the notion that NW-SE oriented contraction is still going on in south-western Sicily, and this result must be considered in evaluation of the seismic hazard of this densely populated area. It is likely that the accumulated strain is released along multiple ruptures in combination with aseismic creep along a seismogenic volume rather than along a single fault plane, as also shown by the great number of events that characterised the 1968 sequence. Thus, further investigations, such as exploratory trenches and dense seismological and geodetic observations along the main displacement zone, are needed to investigate the possible record of focused recent activity and to a more accurate evaluation of kinematics and rate of fault-related fold displacement.

\section{Acknowledgements}

We thank Giusy Lavecchia and an anonymous reviewer for their comments that helped to clarify some aspects of the work. This work was partially funded by the Task D7 "Enhancement of the remote sensing laboratory" of the project, "Programma Triennale di Estensione e Potenziamento dei Sistemi di Monitoraggio Vulcanico e Sismico della Sicilia - Intesa istituzionale di programma del 7 novembre 2003 - APQ del 27/10/2006" funded by the Sicilian Regional Government and by PRIN 2010-11 Project “Active and recent geodynamics of Calabrian Arc and accretionary complex in the Ionian Sea" (responsible C. Monaco). The ENVISAT data were provided in the frame of the ESA CAT.1 5843 project.

\section{References}

Altamimi, Z., Collilieux, X., Legrand, J., Garayt, B., Boucher, C., 2007. ITRF2005: a new release of the International Terrestrial Reference Frame based on time series 
of station positions and Earth Orientation Parameters. Journal of Geophysical Research 112, B09401, http://dx.doi.org/10.1029/2007JB004949.

Anderson, H., Jackson, J., 1987. Active tectonics of the Adriatic Region. Geophys. J. R. Astr. Soc. 91, 937-983.

Antonelli, M., Franciosi, R., Pezzi, G., Querci, A., Ronco, G.P., Vezzani, F., 1988. Paleogeographic evolution and structural setting of the northern side of the Sicily Channel. Memorie Società Geologica Italiana 41, 141-157.

Argnani, A., 1990. The strait of Sicily Rift zone: foreland deformation related of the evolution of back-arc basin. J. Geodyn. 12, 311-331.

Avellone, G., Barchi, M.R., Catalano, R., Morticelli, M.G., Sulli, A., 2010. Interference between shallow and deep-seated structures in the Sicilian fold and thrust belt, Italy. J. Geol. Soc. Lond. 167, 109-126, http://dx.doi.org/ 10.1144/0016-76492008-163.

Barreca, G., Maesano, F.E., Carbone, S., 2010. Tectonic evolution of the Northern Sicanian-Southern Palermo Mountains range in Western Sicily: insight on the exhumation of the thrust-involved foreland domains. Ital. J. Geosci. 129 (3) 234-247.

Barreca, G., Maesano, F.E., 2012. Restraining stepover deformation superimposed on a previous fold-and thrust-belt: a case study from the Mt Kumeta-Rocca Busambra ridges (western Sicily, Italy). J. Geodyn. 55, 1-17, http://dx.doi.org/10.1016/j.jog.2011.10.007.

Bello, M., Franchino, A., Merlini, S., 2000. Structural model of eastern Sicily. Memorie della Società Geologica Italiana 55, 61-70

Bianchi, F., Carbone, S., Grasso, M., Invernizzi, G., Lentini, F., Longaretti, G., Merlini, S. Moscardini, F., 1987. Sicilia orientale: profilo geologico Nebrodi - Iblei. Memorie Società Geologica Italiana 38, 429-458

Ben-Avraham, Z., Boccaletti, M., Cello, G., Grasso, M., Lentini, F., Torelli, L., Tortorici, L., 1990. Principali domini strutturali originatisi dalla collisione nogenicoquaternaria nel Mediterraneo centrale. Memorie della Società Geologica Italian $45,453-462$

Bosi, C., Cavallo, R., Francaviglia, V., 1973. Aspetti geologici e geologico-tecnici del terremoto della Valle del Belice del 1968. Memorie Società Geologica Italiana $12,81-130$.

Bottari, A., 1973. Attività sismica e neotettonica della Valle del Belice. Ann. Geophys. XXVI (1), 55-84.

Bottari, C., Stiros, S.C., Teramo, A., 2009. Archaeological evidence for destructive earthquakes in Sicily between 400 B.C. and A.D. 600. Geoarchaeology 24 (2) 147-175, http://dx.doi.org/10.1002/gea.20260.

Catalano, R., D'Argenio, B., Torelli, L., 1989. A geological section from Sardinia Channel to Sicily Straits based on seismic and field data. In: Boriani, A.B., Piccardo, M., Vai, G.B. (Eds.), The Lithosphere in Italy: Advances in Earth Science Research Atti dei Convegni Lincei, vol. 80. Italian National Commitee for the International Lithosphere Program, Rome, pp. 110-128.

Catalano, R., Franchino, A., Merlini, S., Sulli, A., 2000a. Geologia della Sicilia Occidentale. Guida alle escursioni, $79^{\circ}$ Congresso Nazionale. Società Geologica Italiana 1, 143-155.

Catalano, R., Franchino, A., Merlini, S., Sulli, A., 2000b. Central western Sicily structural setting interpreted from seismic reflection profiles. Memorie della Società Geologica Italiana 55, 5-16.

Custodio, E., 2002. Aquifer overexploitation: what does it mean? Hydrogeol. J. 10, 254-277, http://dx.doi.org/10.1007/s10040-002-0188-6.

Damuth, J.E., 1980. Use of high-frequency (3.5-12 kHz) echograms in the study of near bottom sedimentation processes in the deep sea: a review. Mar. Geol. 38, $51-75$

De Panfilis, M., Marcelli, L., 1968. Il periodo sismico della Sicilia occidentale iniziato il 14 gennaio 1968. Ann. Geophys. XXI (4), 343-421.

Devoti, R., Esposito, A., Pietrantonio, G., Pisani, A.R., Riguzzi, F., 2011. Evidence of large scale deformation patterns from GPS data in the Italian subduction boundary. Earth Planet. Sci. Lett. 311, 230-241, http://dx.doi.org 10.1016/j.epsl.2011.09.034

Dewey, J.F., Helman, M.L., Turco, E., Hutton, D.H.W., Knott, S.D., 1989. Kinematics of the Western Mediterranean. In: Coward, M.P., Dietrich, D., Park, R.G. (Eds.) Alpine Tectonics, vol. 45. Geological Society of London Special Publication, pp. 265-283.

DISS Working Group, 2010. http://diss.rm.ingv.it/diss/, @ INGV 2010.

Farr, T.G., Rosen, P.A., Caro, E., Crippen, R., Duren, R., Hensley, S., Kobrick, M., Paller, M., Rodriguez, E., Roth, L., Seal, D. Shaffer, S., Shimada, J., Umland, J., Werner, M. Oskin, M., Burbank, D., Alsdorf, D., 2007. The shuttle radar topography mission. Rev. Geophys. 45, RG2004, http://dx.doi.org/10.1029/2005RG000183.

Ferranti, L., Oldow, J.S., D’Argenio, B., Catalano, R., Lewis, D., Marsella, E., Avellone, G. Maschio, L., Pappone, G., Pepe, F., Sulli, A., 2008. Active deformation in Southern Italy, Sicily and southern Sardinia from GPS velocities of the Peri-Tyrrhenian Geodetic Array (PTGA). Ital. J. Geosci. 127 (2), 299-316.

Finetti, I.R., Lentini, F., Carbone, S., Del Ben, A., Di Stefano, A., Forlin, E., Guarnieri, P., Pipan, M., Prizzon, A., 2005. Geological outline of Sicily and Lithospheric Tectonodynamics of its Tyrrhenian Margin from new CROP seismic data. In: Finetti, I.R. (Ed.), CROP PROJECT: Deep Seismic Exploration of the Central Mediterraneanand Italy. Elsevier, Amsterdam.

Frepoli, A., Amato, A., 2000. Spatial variation in stresses in peninsular Italy and Sicily from background seismicity. Tectonophysics 317, 109-124, http://dx.doi.org/10.1016/S0040-1951(99)00265-6.

Gasparini, C., Iannaccone, G., Scandone, P., Scarpa, R., 1982. Seismotectonics of the Calabrian Arc. Tectonophysics 84, 267-286.
Guidoboni, E., Muggia, A., Marconi, C., Boschi, E., 2002. A case study in archaeoseismology. The collapses of the Selinunte Temples (Southwestern Sicily): two earthquakes identified. Bull. Seismol. Soc. Am. 92, 2961-2982.

Herring, T.A., King, R.W., McClusky, S.C., 2010. Introduction to GAMIT/GLOBK Release576 10. 4. MIT, Cambridge, MA, pp. 48 pp

Hooper, A., 2008. A multi-temporal InSAR method incorporating both persistent scatterer and small baseline approaches. Geophys. Res. Lett. 35, L16302, http://dx.doi.org/10.1029/2008GL034654.

Lavecchia, G., Ferrarini, F., de Nardis, R., Visini, F., Barbano, S., 2007. Active thrusting as a possible seismogenic source in Sicily (Southern Italy): some insights from integrated structural-kinematic and seismological data. Tectonophysics $445,145-167$

Kampes, B.M., Hanssen, R.F., Perski, Z., 2003. Radar Interferometry with Public Domain Tools, Third International Workshop on ERS SAR Interferometry, 'FRINGE03', Frascati, Italy, 1-5 December 2003., pp. 6 pp.

Marcelli, L., Pannocchia, G., 1971. Uno studio analitico sui dati ipocentrali di 10 terremoti avvenuti in Sicilia occidentale nel Gennaio del 1968. Annali di Geofisica 24 (2), 287-306.

Mattia, M., Bruno, V., Cannavò, F., Palano, M., 2012. Evidences of a contractiona pattern along the northern rim of the Hyblean Plateau (Sicily Italy) from GPS data. Geol. Acta 10 (12), 1-8, http://dx.doi.org/10.1344/105000001705.

McCaffrey, R., Qamar, A.I., King, R.W., Wells, R., Khazaradze, G., Williams, C.A., Stevens, C.W., Vollick, J.J., Zwick, P.C., 2007. Fault locking, block rotation and crustal deformation in the Pacific Northwest. Geophys. J. Int. 169, 1315-1340 http://dx.doi.org/10.1111/j.1365-246X.2007.03371.x.

Mckenzie, D., 1972. Active tectonics of the Mediterranean region. Geophys. J. R. Astron. Soc. 30, 109-185.

Meghraoui, M., Jaegy, R., Lammali, K., Albarede, F., 1988. Late Holocene earthquake sequences on the El Asnam (Algeria) thrust fault. Earth Planet. Sci. Lett. 90, 187-203.

Michetti, A.M., Brunamonte, F., Serva, L., 1995. Paleoseismological Evidence in the Epicentral Area of the January 1968 Earthquakes, Belice, Southwestern Sicily. Bulletin of the Association of Engineering Geologists, Special Publication No. 6 "Perspectives in Paleoseismology". Peanut Butter Publishing, Seattle, WA, USA pp. 127-139.

Michetti, A.M., 2005. Future trends in paleoseismology: integrated study of the seismic landscape as a vital tool in seismic hazard analyses. Tectonophysics 408 , 3-21, http://dx.doi.org/10.1016/j.tecto.2005.05.035.

Monaco, C., Mazzoli, S., Tortorici, L., 1996. Active thrust tectonics in western Sicily (southern Italy): the 1968 Belice earthquakes sequence. Terra Nova 8, $372-381$.

Monaco, C., Tortorici, L., Catalano, S., 2000. Tectonic escape in the Sicanian mountains (western Sicily). Memorie della Società Geologica Italiana 55, 17-25.

Morelli, A., Pondrelli, S., 1998. Il terremoto del Belice del 1968. In: Poster presented at Conference "Trenta anni di terremoti in Italia: dal Belice a Colfiorito", Erice Sicily 14-18 July.

Palano, M., Ferranti, L., Monaco, C., Mattia, M., Aloisi, M., Bruno, V., Cannavò, F. Siligato, G., 2012. GPS velocity and strain fields in Sicily and southern Calabria, Italy: updated geodetic constraints on tectonic block interaction in the central Mediterranean. J. Geophys. Res. 117, B07401.

Pepe, F., Sulli, A., Agate, M., Di Maio, D., Kok, A., Lo Iacono, C., Catalano, R., 2003. Plio-Pleistocene geological evolution of the northern Sicily continental margin (southern Tyrrhenian Sea): new insights from high-resolution, multi-electrode sparker profiles. Geo-Mar. Lett. 23, 53-63.

Rovida, A., Camassi, R., Gasperini, P., Stucchi, M., 2011. CPTI11, The 2011 Version of the Parametric Catalogue of Italian Earthquakes, Milano, Bologna. http://emidius.mi.ingv.it/CPTI

Pondrelli, S., Salimbeni, S., Ekström, G., Morelli, A., Gasperini, P., Vannucci, G., 2006 The Italian CMT dataset from 1977 to the present. Phys. Earth Planet. Inter. 159, 286-303, http://dx.doi.org/10.1016/j.pepi.2006.07.008.

Rigano, R., Antichi, B., Arena, L., Azzaro, R., Barbano, M.S., 1999. Sismicità e zonazione sismogenetica in Sicilia occidentale. In: Atti 17 Convegno GNGTS, Rome, November 10-12 1998. CDROM.

Roure, F., Howell, D.G., Muller, C., Moretti, I., 1990. Late Cenozoic subduction complex of Sicily. J. Struct. Geol. 12 (2), 259-266.

Rosen, P.A., Henley, S., Peltzer, G., Simons, M., 2004. Updated repeat orbit interferometry package released, Eos, Transactions, AGU 85 (5), 47.

Scandone, P., Patacca, E., Meletti, C., Bellatalla, M., Perilli, N., Santini, U., 1992. Struttura geologica, evoluzione cinematica e schema sismotettonico della penisola italiana, vol. 1. In: GNDT-CNR. Zonazione e riclassificazione sismica. Atti de Convegno di Pisa, 25-27 Giugno 1990, pp. 119-135.

Sgroi, T., De Nardis, R., Lavecchia, G., 2012. Crustal structure and seismotectonics of central Sicily (southern Italy): new constraints from instrumental seismicity. Geophys. J. Int. 189, 1237-1252.

Tortorici, L., Monaco, C., Mazzoli, S., Bianca, M., 2001. Timing and modes of deformation in the western Sicilian thrust system, southern Italy. J. Petrol. Geol. 24 (2), 191-211.

Visini, F., De Nardis, R., Lavecchia, G., 2010. Rates of active compressional deformation in central Italy and Sicily: evaluation of the seismic budget. Int. J. Earth Sci. 99, 243-264.

Wells, D.L., Coppersmith, K.J., 1994. New empirical relationships among magnitude, rupture length, rupture width, rupture area, and surface displacement. Bull Seismol. Soc. Am. 84, 974-1002. 